\title{
追悼 河合雅雄先生
}

渡邊邦夫 ${ }^{*}$

私が河合雅雄先生と初めてお会いしたのは、1972年 の1月、できたばかりの大学院入学が決まって、事前 に犬山を訪れた時であった。河合先生は1924年生まれ だから、まだ40歳代後半だったわけである。今思い出 してみてもあの頃は、名の知られた大物教授がたくさ ん部屋を並べており、また外部からもやってくる時代 であった。当時の河合先生は、時折㚘頁をヒクヒクさせ ながら、神経質そうに話す方だった。それも無理はな いと思うのだが、あの当時は霊長類研究所の協議員会 は、午後 1 時に始まって延々と続き、深夜にまで及ぶ ことも珍しくなく、新しくできた研究所の活気をみな ぎらせていたが、一方でやれやれ何をそんなに言い争 わなければならないのかと、田舎出の私にはいぶかし く思えることでもあった。まだ大学紛争の名残も残っ た雲囲気の中で、教官の多くも若い人ばかりだった。そ れが分野を超えて酒を飲みながら議論をし、あるいは 宿直の事務官たちと麻雀卓を囲んだりしていた。そん な時代だったのである。

そんな中で河合先生は、京大出身フィールド系の中 心人物だったのだから、日々の気苦労はさぞかし大変 だったことであろう。さらにまた、ではフィールド系 教官が良くまとまっていたかというと決してそうでは ない。私はその頃一度河合先生にその点についてお訊 ねしたことがあるのだが、「サル・グループはな、日頃 は喧嘩ばっかりしていても、いざとなるとしっかり団 結するのや」というお答えだった。だが長く霊長類研 究所に在籍して、私がそれを実感したことは一度もな い。河合先生は若い頃に結核をやり、またアフリカで 事故にあったりして、片肺である。時々熱が出るとか で、咒談で「Aの近くにいると酸素が全部吸いとられ てしまって息苦しくなるのや」などと言って、笑って いた。河合先生はその後もいくつも病気を経験し、ア フリカに行っては寄生虫ロアロアをもらったとかで、そ れが皮膚の下や目の中を動いていったなどということ もあった。いわば病気のデパート、総合商社のようで ありながら、97歳まで生きられたのだから、恐れ入る
しかない。

私は、もともと東南アジア志向でアフリカに魅力を 感じなかったことから、河合先生は私の指導教官では なかった。あの頃の院生は、生意気にも講義などはい らない、フィールドに早く行かせてくれなどと言って、 入学時の一時を除くと講義はほとんど断ってしまった。 そして私は福井県若狭地方のフィールドに下宿を構え て住んでいたぐらいなので、学生時代の河合先生の記 憶は余り残っていない。しかしながらそういう身体で、 新設された霊長類研究所には幸島野外観察施設を設け られ、一方では石川県の白山自然保護センターの創立 にも梁くかかわられていた。近年では兵庫県森林動物 研究センターの設立に大きな力を発揮され、またモン キーセンターや霊長類研究所のスタートにも関わって いたはずである。私などの凡才には、どこからそんな 腕力が生み出されたのか、今もって良く分からない。

河合先生は、「依頼された時にイメージが浮か心゙ば書 ける。だがイメージが浮かばないと書けない」とよく 言われた。河合先生の書かれたものは、非常に読みや すく、平明である。原稿用紙にすらすらと書けて、何 度も書き直すことはそうはないとのことであった。私 には、その辺が読みやすさ、分かりやすさの秘密だと 思われるが、一方で幸島におけるオスザルのボス争い の話などは、如何にも擬人主義的に感じられた。初期

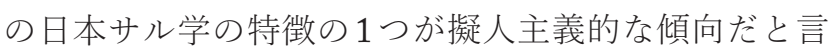
われるが、その辺を私の指導教官だった川村俊蔵先生 は「分かるということが大事」と言っておられた。また 河合先生には「言葉を大事にしなさい」と言われた。そ してその実例として自分が用いた「基礎順位」「依存順 位」や「文化行動」の実例を挙げられた。最初期のサル 学研究者の中ではこうした「共感主義」は共通していた ことだと思うが、問題は「分かり方」が人によって異な ることである。1970年代当時は、「ボスザル」や「リー ダー」などと言った概念・「言葉」が、研究者の間で大 きな議論になっていた。私にはあの頃の対立の背景に は、戦前の教育を受けた年長世代と、戦後民主主義の 
下での教育を受けた若い世代の間の感覚・感受性の違 い・ズレも大きく影響していたように思われる。河合 先生が 1965 年に出版された『ニホンザルの生態』は、こ うした最初期の日本サル学の成果を、きっちりとその 考え方でまとめた労作であった。どう読まれるかは別 として、あの本こそ英訳されて世界に届けられるべき だったと、私は思う。

さて、私が河合先生と親しくお付き合いさせていた だいたのは、私が幸島野外観察施設の助手として赴任 してからのことだった。私は大学院生だった頃から「河 合さんの大家族主義」ということを何度か耳にしてい た。具体的にそれがどういうことを意味していたのか、 私が正確に理解しているわけではない。60歳を過ぎた 頃からの河合先生からは、煩がヒクヒクする話し方は なくなっていた。霊長類研究所も落ち着いたし、すで に大御所的な存在になられた河合先生には、十分な余 裕・ゆとりが感じられるようになっていた。そして気 ゔかされたのは、人付き合いの巧さ、緻密さと幅広さ だった。幸島はかつて売りに出されようとしたことが あったが、当時対立した串間市長らとも懷かしげに話 のできる関係を築いておられた。私も、できたばかり の財団からの研究費（私には大金だった）を世話しても らったことがあるが、先に触れた政治的な腕力の強さ は、こうして創り上げられた強固な人脈の中にこそあ るのであろう。私などは、そういう晚年の河合先生に 上手に取り込んでいただいた 1 人である。

河合先生のそうした親密な付き合い方はずっと続い ていたと思われる。幸島の三戸さんとも何くれとなく 連絡を取り合っており、三戸さんも頼りにされていた。 河合先生の存在を語る時に、奥さんの良子さんを忘れ るわけにはいかないと思うのだが、良子さんは「河合 を使ってくださいね」と言うのが常だった。病身の河 合先生を気遣いながら、2人でさまざまなことに対処 してこられたのであろう。今でも記憶に残っているの だが、今西先生が亡くなった晚、私は河合さんの家に 招かれて、酒を頂いていた。報道関係からは次々と電 話がかかってきて、いつまで経っても終わらない。と うとうしびれを切らした河合先生は、良子さんに「も う電話に出るのは止めなさい。どうせここにかかって くるのはBと Cの後なのだから」と言われた。ああこ の人たちは、サル・グループの中でも自分たちのポジ ションをよく理解して動いておられるのだなと思った のである。そうしながら、さらに自分の新たな分野を 広げていく。一方で、川村先生が戦争体験を話されて、 その当時の辛い経験が自分の原点だと言っておられた と話した時、河合先生は「そうか川村もそうだったの か」と言われて驚いたこともある。共通した時代を同 じような思いでサル学に打ち込んだとしても、そのよ

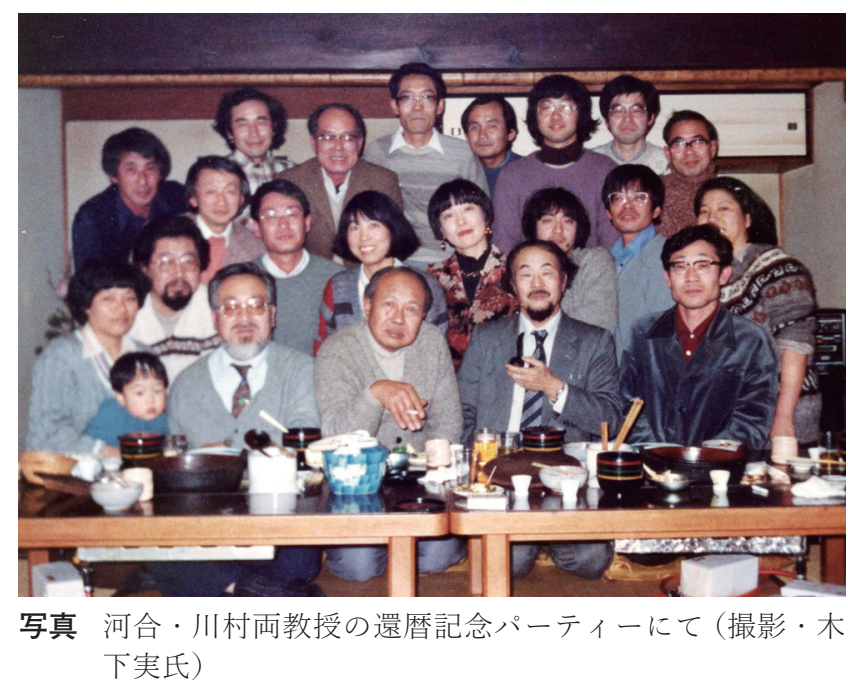

うなことは改めてお互い話し合うことではなかったの であろう。

河合先生は晚年になってから何度か東南アジアを歴 訪され、そのお供をした。スラウェシやタイ、マレー シアなどであるが、いつも控えめにじっと見守ってく れていた。研究の内容に口出しすることも、知識をひ けらかすことも全くなかった。「君たちは切り込み隊長 なのだから、個別の良い仕事をしていかなければいか ん」というのが口癖であった。アフリカでの調査にも 病気のために少し遅れて本格的に参加していった河合 先生だから、すでに多くの人たちによって進められて いた類人猿ではなくて、ヒヒの交雑個体群やゲラダヒ ヒ、マンドリルの研究などを選ばれたのであろう。決 して無理はされなかったが、健康には十分注意されて いた。マレーシアではすでにマラリアの薬を自由に手 に入れることはできなかった。あわてて医者に頼み込 んで、非衛生的な土地に行くのだからということで、抗 マラリア薬を処方してもらったこともあった。

報道によれば今、河合先生が長年研究を進めてこら れた霊長類研究所は危機の最中にある。その結末を知 ることなく逝かれたというのを僥倖と考えるのかどう か、それを避けることができなかった我々後輩には、慚 愧に堪えないものがある。お前は、すでに幸島観察所 を野生動物研究センタ一設立の「原資」として提供して いるではないかと言われるかも知れないが、あの時は 長期継続観察の謳い文句は良いとして、深刻なアイデ アの枯渇に悩んでいた。文科省からは本当に幸島も移 管してしまって良いのかという問い合わせがあったと いう。新しい革袋が必要であり、新たな出発を期待し たのだった。だが今回の問題は如何にも唐突であり、私 にはなんとも納得がいかない。このようなことを踏ま えて、河合先生を見送らなければならないことを、非 常に残念に思う。 